\title{
Analisis kesiapan mahasiswa jurusan pendidikan fisika menggunakan e-learning dalam situasi pandemi Covid-19
}

\author{
Bayu Setiaji $^{1 *}$, Pri Ariadi Cahya Dinata ${ }^{2}$ \\ ${ }^{1}$ Jurusan Pendidikan Fisika, Fakultas Matematika dan Ilmu Pengetahuan Alam, Universitas Negeri Yogyakarta. \\ Jalan Colombo No. 1, Karangmalang, Yogyakarta 55281, Indonesia. \\ ${ }^{2}$ Program Studi Pendidikan Fisika, Fakultas Keguruan dan Ilmu Pendidikan, Universitas Palangka Raya. \\ Jalan Yos Sudarso, Menteng, Palangka Raya, Indonesia. \\ * Corresponding Author. Email: bayu.setiaji@uny.ac.id
}

Received: 7 May 2020; Revised: 15 May 2020; Accepted: 26 May 2020

\begin{abstract}
Abstrak: Efektivitas dari penerapan e-learning di perguruan tinggi pada situasi pandemi Covid 19 dipengaruhi beberapa faktor. Faktor yang paling penting adalah kesiapan mahasiswa menggunakan e-learning dalam proses perkuliahan. Tujuan dari penelitian ini adalah untuk mengetahui tingkat kesiapan mahasiswa pendidikan fisika dalam menggunakan e-learning. Dengan mengetahui tingkat kesiapan mahasiswa, dosen dan pemangku kebijakan dapat mempersiapkan kebijakan pengembangan lebih lanjut. Metode yang digunakan adalah survei. Kesiapan mahasiswa menggunakan e-learning diukur dengan menggunakan angket kesiapan mahasiswa. Angket kesiapan mahasiswa yang dikembangkan berdasarkan pada instrumen model Aydin dan Tasci. Angket kesiapan mahasiswa ini memiliki 25 pernyataan dengan 4 indikator. 75 mahasiswa pendidikan fisika dilibatkan dalam penelitian ini. Hasil pengisian angket dianalisis dengan menggunakan metode suksesif interval kemudian dikategorikan ke dalam skala penilaian kesiapan e-learning. Hasil penelitian menunjukkan bahwa mahasiswa Jurusan Pendidikan Fisika Universitas Negeri Yogyakarta termasuk dalam kategori siap pada 3 indikator dan tidak siap pada 1 indikator. Hal ini dapat dijadikan evaluasi bagi para dosen dan pemangku kebijakan agar kesiapan mahasiswa dapat lebih ditingkatkan.
\end{abstract}

Kata Kunci: e-learning, kesiapan mahasiswa, pandemic Covid-19

\section{Analysis of e-learning readiness on physics education students during Covid-19 pandemic}

\begin{abstract}
The effectiveness of e-learning implementation in University during Covid-19 Pandemic is depending on several factors. The most important factor is the readiness of students using e-learning in the studying process. The aim of this research is to know physics education student's readiness in using e-learning. By knowing student's e-learning readiness, lecturer and stakeholders would be able to prepare further development of e-learning. The method in this research is survey method. Student's e-learning readiness is measured by using student's e-learning readiness questionnaire. This questionnaire is developed based on Aydin and Tasci Model. This questionnaire has 25 statements and 4 indicators. 75 students involved in this research. The results are analyzed using successive interval method then categoryzed using e-learning readiness scale. The results show that Physics Education Students of UNY are ready in 3 indicators and not ready in only 1 indicator. This result could be an evaluation for lecturers and stakeholders to increase student's e-learning readiness.
\end{abstract}

Keywords: e-learning, student's readiness, Covid-19 pandemic

How to Cite: Setiaji, B., \& Dinata, P. (2020). Analisis kesiapan mahasiswa jurusan pendidikan fisika menggunakan e-learning dalam situasi pandemi Covid-19. Jurnal Inovasi Pendidikan IPA, 6(1), 59-70. doi:https://doi.org/10.21831/jipi.v6i1.31562

\section{PENDAHULUAN}

Pandemi Coronavirus Disease 2019 atau biasa disebut Covid 19 menggemparkan dunia pada tahun 2020 ini. Menurut World Health Organization (WHO), Covid 19 merupakan penyakit menular yang disebabkan oleh coronavirus jenis baru. Coronavirus pertama kali ditemukan di Wuhan, Tiongkok, Bulan Desember 2019 (World Health Organization, 2020). 


\section{Jurnal Inovasi Pendidikan IPA, 6 (1), 2020 - 60}

Bayu Setiaji, Pri Ariadi Cahya Dinata

Penyebaran virus ini begitu cepat. Hal ini disebabkan oleh mudahnya Covid 19 ditularkan. WHO menjelaskan bahwa Covid 19 dapat menyebar melalui percikan-percikan air dari hidung atau mulut yang keluar saat orang yang terjangkit Covid 19 batuk atau bersin (World Health Organization, 2020). Percikan-percikan air tersebut lalu jatuh dan mengenai benda dan permukaan di sekitarnya. Orang sehat yang menyentuh benda yang sudah terinveksi tersebut kemudian apabila menyentuh mata, mulut, atau hidung dapat tertular. Akibatnya Covid-19 telah menyebar hingga ke lebih dari 200 negara hanya dalam tempo kurang dari 6 bulan (World Health Organization, 2020).

Krisis Covid 19 ini menjadi tantangan bagi negara kita dan juga seluruh dunia. Krisis Covid 19 ini memengaruhi segala aspek kehidupan termasuk pendidikan. Pada situasi pandemi Covid 19 ini, mahasiswa Indonesia dan mahasiswa lain di seluruh dunia dipaksa untuk dapat belajar dari rumah. Hal ini bertujuan untuk dapat memutus mata rantai penyebaran Covid 19.

Kegiatan belajar di rumah sering dikaitkan dengan pembelajaran daring (dalam jaringan) atau $e$ learning. E-learning merupakan penggunaan teknologi informasi dan komunikasi pada proses belajar mengajar (Hasan, 2017; Muthuchamy \& Thiyagu, 2011; Rosenberg \& Foshay, 2002; Setiawan et al., 2019; Setyoningsih, 2015). Dengan menerapkan pembelajaran e-learning ini, mahasiswa dan dosen di perguruan tinggi di Indonesia akhirnya menyadari bahwa pembelajaran dapat dilakukan di manapun dan kapanpun. Hal ini menurut Ali et al. (2010) membuat pembelajaran dapat berlangsung lebih efektif dan efisien.

Banyak sekali platform e-learning yang dapat diakses baik oleh dosen maupun mahasiswa. Edmodo, Modle, Google Classroom merupakan contoh platform e-learning yang menyediakan fasilitas LMS (Learning Management System). LMS merupakan sistem yang menyediakan kelas berbasis teknologi informasi dan komunikasi yang dapat diisi oleh dosen dengan materi, tugas, sumber belajar dan lain-lain (Shawar \& Al-Sadi, 2010). Sistem ini juga memfasilitasi komunikasi antara dosen dengan mahasiswa. Selain itu, ada juga Zoom, Google Meet, Skype yang dapat digunakan untuk video conference.

Keuntungan lain dalam penggunaan e-learning adalah meningkatkan kemampuan literasi sains dan berpikir analisis (Setiaji \& Jumadi, 2018), menambah motivasi (Wardono et al., 2016), meningkatkan efektivitas komunikasi (Al-Said, 2015), memfasilitasi tahap asimilasi dan akomodasi yang lebih baik (Dinata et al., 2020), meningkatkan kesiapsiagaan dan mempersingkat waktu pembelajaran (Ravitz \& Blazevski, 2014).

Efektivitas dari penggunaan e-learning dipengaruhi banyak hal. Kemampuan adaptasi dan adopsi yang baik sangat menentukan efektivitas e-learning (Wannemacher, 2006). Berkaitan dengan efektivitas e-learning, yang juga menjadi penting adalah faktor penerimaan seseorang terhadap sistem informasi dan komunikasi baru. Kesiapan mahasiswa dalam menggunakan e-learning menjadi faktor yang paling utama dalam menentukan efektivitas e-learning selain faktor-faktor yang lain.

Aydin dan Tasci (2005) mengembangkan suatu model yang mengukur kesiapan dalam implementasi e-learning. Mereka berpendapat bahwa ada empat faktor yang menentukan e-learning yaitu faktor teknologi, inovasi, manusia, dan pengembangan diri.

Dibutuhkan suatu analisis mengenai kesiapan e-learning sebelum mengimplementasikannya. Hasil penelitian kesiapan penggunaan e-learning dari Fariani (2013) yang mengadopsi model Aydin dan Tasci (2005) menunjukkan bahwa masih ada perguruan tinggi yang belum siap dalam penerapan $e$ learning. Dengan mengetahui kategori belum siapnya perguruan tinggi tersebut, peneliti dapat memberikan solusi. Solusi yang diberikan antara lain pembuatan manajemen yang baik, peningkatan infrastruktur dan juga peningkatan sumber daya manusia. Penelitian lain dari Angraini dan Suryadi (2015) menunjukkan bahwa Universitas Islam Negeri Suska Riau yang belum siap dengan tingkat kesiapan 3,36 .

Hasil penelitian lain yaitu dari Faslah dan Santoso (2017) menunjukkan bahwa penggunaan analisis kesiapan implementasi e-learning pada Politeknik Hasnur. Hasil penelitian menunjukkan kategori siap. Namun masih ada beberapa peningkatan yang harus dilakukan antara lain peningkatan teknologi dan inovasi dan juga peningkatan pengembangan diri dari dosen maupun dari mahasiswa. Peneliti juga menyarankan adanya pelatihan terkait dengan pembelajaran e-learning pada mahasiswa maupun dosen untuk meningkatkan tingkat kesiapan penggunaan e-learning.

Selain pada perguruan tinggi, analisis e-learning juga digunakan dalam menilai kesiapan sekolah dalam menerapkan e-learning. Hasil penelitian Waryanto dan Insani (2013) yang melakukan analisis kesiapan e-learning pada SMA Kota Yogyakarta yang menunjukkan hasil cukup siap. 


\section{Jurnal Inovasi Pendidikan IPA, 6 (1), 2020 - 61}

Bayu Setiaji, Pri Ariadi Cahya Dinata

Universitas Negeri Yogyakarta (UNY) sudah bertindak terkait penanganan Covid-19 melalui Surat Edaran Rektor UNY Nomor 1 Tahun 2020 tentang antisipasi penyebaran virus corona di UNY. Surat edaran ini berisi tentang himbauan kepada seluruh warga kampus UNY untuk mencuci tangan dengan sabun, menggunakan masker, menjaga kebersihan, menjaga daya tahan tubuh, memerhatikan etika batuk dan bersin, dan tidak melakukan perjalanan ke negara terjangkit (Rektor Universitas Negeri Yogyakarta, 2020c). Berdasarkan pada Surat Edaran Rektor UNY Nomor 1 Tahun 2020, dikeluarkan pula petunjuk praktis pembelajaran daring UNY. Petunjuk praktis ini dapat memermudah dosen dan mahasiswa dalam mengikuti pembelajaran online.

Kemudian dilanjutkan dengan dikeluarkannya Surat Edaran Rektor UNY Nomor 2 Tahun 2020 tentang kewaspadaan terhadap penyebaran Covid-19. Surat Edaran ini menindaklanjuti Surat Edaran Rektor UNY Nomor 1 Tahun 2020. Dalam Surat Edaran ini, juga berisi tentang penangguhan kegiatan akademik maupun non-akademik yang melibatkan narasumber dan peserta dari negara-negara terdampak Covid-19 (Rektor Universitas Negeri Yogyakarta, 2020d).

Dasar dari kegiatan e-learning dilingkungan kampus UNY adalah Instruksi Rektor UNY Nomor 1 Tahun 2020 tentang pelaksanaan kegiatan pembelajaran, layanan akademik, dan layanan umum untuk pencegahan penyebaran Covid-19 di UNY. Ada delapan instruksi yang isinya antara lain perkuliahan teori dilakukan secara daring/online dengan berbagai platform LMS yang tersedia, penangguhan praktikum dan sejenisnya, penangguhan perkuliahan lapangan, pelaksanaan bimbingan tugas akhir dilakukan secara online, ujian akhir diatur oleh fakultas, mobilitas warga kampus UNY pada tingkat nasional maupun internasional ditangguhkan, kegiatan layanan akademik tetap berjalan, dan anjuran untuk tidak datang ke kampus (Rektor Universitas Negeri Yogyakarta, 2020a).

Kemudian dikeluarkan Surat Edaran Rektor UNY Nomor 3 Tahun 2020 sebagai tindak lanjut dari Instruksi Rektor UNY Nomor 1 Tahun 2020 tentang pelaksanaan kegiatan pembelajaran, layanan akademik, dan layanan umum untuk pencegahan penyebaran Covid-19 di Universitas Negeri Yogyakarta. Surat edaran ini menjelaskan langkah-langkah work from home atau bekerja di rumah bagi dosen dan pegawai di lingkungan UNY (Rektor Universitas Negeri Yogyakarta, 2020e).

UNY juga membentuk tim Covid-19 Crisis Center (3C) dengan dasar Keputusan Rektor UNY Nomor 31.16/UN34/III/2020 tentang tim Covid-19 Crisis Center (3C). Tim 3C ini bertugas untuk mensosialisasikan, mempersiapkan, melaksanakan, dan mempertanggungjawabkan pelaksanaan kegiatan penanggulangan Covid-19 di lingkungan kampus UNY (Rektor Universitas Negeri Yogyakarta, 2020b).

Surat Edaran Rektor UNY Nomor 9 Tahun 2020 tentang pelaksanaan perkuliahan semester genap 2019/2020 pada masa tanggap darurat bencana Covid-19 di Universitas Negeri Yogyakarta menjelaskan terkait dengan mekanisme perkuliahan. Dalam surat edaran ini dijelaskan tentang pelaksanaan perkuliahan yang melalui online, pelaksanaan ujian akhir semester, serta mekanisme input nilai bagi dosen (Rektor Universitas Negeri Yogyakarta, 2020f).

Melalui peraturan-peraturan tersebut, UNY terbukti serius dalam penanggulangan pandemi Covid-19 di lingkungan kampus. Dengan dibentuknya Tim 3C membuat pelayanan terkait penangulangan pandemi Covid-19 menjadi semakin baik dan terfokus. UNY juga menekankan agar kegiatan perkuliahan dilaksanakan secara e-learning di rumah sampai pandemi Covid-19 selesai.

Jurusan Pendidikan Fisika Universitas Negeri Yogyakarta pada situasi pandemi Covid-19 melakukan pembelajaran e-learning. Analisis dalam penelitian ini bertujuan untuk menilai kesiapan mahasiswa Jurusan Pendidikan Fisika UNY dalam menggunakan teknologi e-learning. Analisis ini hanya terfokus pada mahasiswa saja dengan harapan agar dapat mengetahui secara lebih jelas gambaran kesiapan mahasiswa dalam melaksanakan e-learning. Dengan mengetahui kesiapan mahasiswa, Dosen dan pemangku kebijakan dapat menerapkan suatu kebijakan dan strategi terkait pengembangan $e$ learning yang akan dilakukan.

\section{METODE}

Penelitian ini merupakan penelitian deskriptif. Tujuan dari penelitian ini adalah untuk mendapatkan gambaran dari kesiapan mahasiswa Pendidikan Fisika UNY terkait dengan pelaksanaan kegiatan $e$ learning. Metode yang digunakan adalah survei dengan menyebarkan angket kesiapan mahasiswa secara online ke 75 mahasiswa Pendidikan Fisika UNY. Pengisian angket menggunakan bantuan Google Form dengan memastikan bahwa satu mahasiswa hanya dapat mengisi angket 1 kali. 
Penelitian ini menggunakan instrumen angket dengan 25 butir pernyataan. Ada empat indikator yang diukur pada angket. Indikator pertama adalah keterampilan menggunakan komputer/smartphone. Indikator pertama ini berkaitan dengan kemampuan dalam mengoperasikan software dan hardware komputer, pengoperasian smarthphone, serta menyelesaikan masalah pada komputer dan smartphone. Indikator kedua adalah pemahaman terhadap teknologi e-learning. Indikator kedua berkaitan dengan pemahaman konsep e-learning dan kebiasaan dalam menggunakan internet untuk belajar mandiri. Indikator ketiga adalah kesiapan menerima materi pembelajaran melalui $e$-learning. Indikator ini diwakili dengan pernyataan terkait perangkat keras yang dimiliki mahasiswa, koneksi internet yang tersedia, serta pengalaman menerima $e$-learning di masa lalu. Indikator terakhir adalah sikap positif mahasiswa terhadap teknologi komputer dan internet. Indikator terakhir ini berkaitan dengan perubahan sikap, persepsi, motivasi, dan kepercayaan diri mahasiswa tentang e-learning. Rincian pernyataan angket untuk tiap indikator dapat dilihat pada Tabel 1.

Tabel 1. Pernyataan angket kesiapan e-learning

\begin{tabular}{|c|c|}
\hline Indikator & Pernyataan \\
\hline $\begin{array}{l}\text { Keterampilan } \\
\text { menggunakan } \\
\text { komputer/ } \\
\text { smartphone }\end{array}$ & $\begin{array}{l}\text { 1. Saya mampu mengoperasikan sofwere Microsoft Office meliputi Microsoft Word, } \\
\text { Power Point dan Excel. } \\
\text { 2. Saya dapat melakukan operasi file antara media penyimpanan file (Flashdisk, CD, } \\
\text { DVD, atau Harddisk). } \\
\text { 3. Saya mampu mengetik menggunakan komputer dengan lancar. } \\
\text { 4. Saya mampu mengoperasikan komputer dan smartphone dengan terampil. } \\
\text { 5. Saya mengetahui bagaimana cara menyelesaikan masalah pada komputer dan } \\
\text { smartphone baik di sisi hardware maupun softwere. } \\
\text { 6. Saya terbiasa menggunakan komputer/smartphone saya untuk mendukung } \\
\text { pembelajaran. }\end{array}$ \\
\hline $\begin{array}{l}\text { Pemahaman } \\
\text { terhadap teknologi } \\
\text { e-learning }\end{array}$ & $\begin{array}{l}\text { 7. Saya memahami konsep pembelajaran online. } \\
\text { 8. Saya mampu menggunakan layanan internet (web browser, search engine atau } \\
\text { email). } \\
\text { 9. Saya memahami tata cara pelaksanaan pembelajaran online. } \\
\text { 10. Saya terbiasa berkomunikasi atau berdiskusi secara online dengan teman-teman di } \\
\text { kelas melalui aplikasi WhatsApp, Line, dll. } \\
\text { 11. Saya menguasai LMS (Learning Management System) seperti besmart, Edmodo, } \\
\text { Google Classroom, dll. } \\
\text { 12. Saya memahami tata cara menggunakan fasilitas video conference untuk keperluan } \\
\text { pembelajaran online seperti skype, besmart, zoom, dll. } \\
\text { 13. Saya mampu memanfaatkan fitur-fitur pembelajaran online yang meliputi } \\
\text { download materi, diskusi online, upload tugas, menjawab kuis, ujian online atau } \\
\text { bertanya online. }\end{array}$ \\
\hline $\begin{array}{l}\text { Kesiapan } \\
\text { menerima materi } \\
\text { pembelajaran } \\
\text { melalui e-learning }\end{array}$ & $\begin{array}{l}\text { 14. Saya memiliki peralatan komputer/smartphone. } \\
\text { 15. Saya memiliki koneksi internet yang memadai untuk melaksanakan pembelajaran } \\
\text { online. } \\
\text { 16. Saya memiliki akun pembelajaran online. } \\
\text { 17. Saya mempersiapkan diri dengan belajar sebelum e-learning dimulai. } \\
\text { 18. Saya mengunduh dan mempelajari semua materi kuliah yang ada pada e-learning. }\end{array}$ \\
\hline $\begin{array}{l}\text { Sikap terhadap } \\
\text { TIK }\end{array}$ & $\begin{array}{l}\text { 19. Kegiatan e-learning mampu meningkatkan minat belajar saya. } \\
\text { 20. E-learning meningkatkan motivasi belajar saya. } \\
\text { 21. E-learning mempermudah saya dalam mengakses materi kuliah. } \\
\text { 22. E-learning meningkatkan kualitas berkomunikasi dengan dosen dan mahasiswa. } \\
\text { 23. E-learning mempermudah saya dalam memahami materi perkuliahan serta tugas- } \\
\text { tugas yang diberikan dosen. } \\
\text { 24. E-learning meningkatkan kepercayaan diri saya dalam belajar. } \\
\text { 25. E-learning meningkatkan efektifitas waktu dalam pembelajaran. }\end{array}$ \\
\hline
\end{tabular}

Sebelum digunakan, angket dinilai validitasnya oleh 6 dosen ahli untuk memastikan bahwa angket valid. Ada tiga aspek yang dinilai dalam uji validitas angket yaitu: (1) kesesuiaan pernyatan dengan indikator, (2) konstruksi, dan (3) kebahasaan.

Hasil uji validitas angket kemudian dianalisis dengan menggunakan teknik perhitungan koefisien validitas konten (CVR) yang dikembangkan oleh Lawshe (1975). Perhitungannya adalah sebagai berikut. 


\section{Jurnal Inovasi Pendidikan IPA, 6 (1), 2020 - 63}

Bayu Setiaji, Pri Ariadi Cahya Dinata

$C V R=\left(\frac{n_{e}-\frac{N}{2}}{\frac{N}{2}}\right)$

CVR adalah content valdity ratio, $n_{e}$ adalah jumlah validator yang menjawab "item dapat digunakan", dan $\mathrm{N}$ adalah jumlah validator. Penentuan kategori dari validitas instrumen mengacu pada kategori yang dikemukakan oleh Azwar (2015) pada Tabel 2.

Tabel 2. Kriteria Kategori CVR

\begin{tabular}{cc}
\hline Skor CVR & Kategori \\
\hline$>0,35$ & Sangat Berguna \\
$0,21-0,35$ & Berguna \\
$0,11-0,20$ & Tergantung Keadaan \\
$<0,11$ & Tidak Berguna \\
\hline
\end{tabular}

Selanjutnya untuk mengukur tingkat kesiapan mahasiswa, data hasil pengisian angket yang berupa data ordinal diubah terlebih dahulu ke data interval. Hal ini dilakukan karena data ordinal pada angket merupakan data kualitatif atau bukan merupakan angka yang sebenarnya. Angka yang ada dalam data ordinal hanya merupakan simbol sehingga perhitungan statistik tidak dapat dilakukan.

Pengubahan data hasil pengisian angket ini menggunakan analisis metode suksesif interval. Langkah pertama dalam metode suksesif interval adalah menghitung frekuensi tanggapan mahasiswa dari masing-masing pilihan jawaban. Kemudian setelah itu, langkah kedua adalah menghitung proporsi dengan cara membagi setiap frekuensi dengan jumlah total responden yang dalam penelitian ini ada 75 responden. Langkah selanjutnya adalah menghitung nilai proporsi kumulatif dengan cara menjumlahkan proporsi secara berurutan untuk setiap nilai.

Langkah keempat adalah mencari nilai z dengan menggunakan bantuan tabel z. Asumsi yang digunakan adalah proporsi kumulatif berdistribusi normal baku. Setelah nilai z ditemukan, langkah selanjutnya adalah mencari nilai $\mathrm{F}$ dengan persamaan $F=\frac{1}{\sqrt{2 \pi}} \operatorname{Exp}\left(-\frac{1}{2} z^{2}\right)$.

Langkah selanjutnya adalah menghitung scale value. Setelah nilai scale value ditemukan, langkah terakhir adalah menghitung nilai hasil penskalaan. Semua langkah tersebut dapat dihitung dengan menggunakan bantuan Microsoft Excel.

Setelah data hasil pengisian angket diubah menjadi data interval, kemudian data dianalisis dengan menggunakan model Aydin dan Tasci (2005) tentang kesiapan implementasi e-learning. Masing-masing butir pernyataan pada masing-masing indikator pada angket akan dianalisis. Tingkat kesiapan mahasiswa dalam pelaksanaan e-learning dapat digambarkan dengan skala penilaian seperti pada Tabel 3 .

Tabel 3. Skala Penilaian Kesiapan e-learning

\begin{tabular}{cl}
\hline Skala & \\
\hline$>4,2$ & Siap \\
& Penerapan e-learning dapat dilanjutkan \\
$3,4-4,1$ & Siap \\
& Membutuhkan sedikit peningkatan \\
$2,6-3,3$ & Tidak siap \\
& Membutuhkan sedikit peningkatan \\
& Tidak siap \\
& Membutuhkan banyak peningkatan \\
\hline
\end{tabular}

\section{HASIL DAN PEMBAHASAN}

Hasil analisis dari uji validitas angket kesiapan mahasiswa yang diuji oleh enam dosen ahli ditunjukkan pada Tabel 4. Berdasarkan hasil analisis uji validitas angket kesiapan mahasiswa pada Tabel 4 dapat disimpulkan bahwa semua item angket sudah valid dan dapat digunakan dalam penelitian. Hal ini ditunjukkan oleh nilai CVR yang menunjukkan nilai 1. Menurut Azwar (2015), nilai 1 ini termasuk dalam kategori sangat berguna seperti yang ditunjukkan pada Tabel 2 .

Selanjutnya setelah angket dinyatakan valid oleh para ahli, angket dapat digunakan dalam penelitian. Sebagaimana telah dijelaskan sebelumnya data pengisian angket oleh mahasiswa merupakan data ordinal yang harus diubah terlebih dahulu menjadi data interval. 
Jurnal Inovasi Pendidikan IPA, 6 (1), 2020 - 64

Bayu Setiaji, Pri Ariadi Cahya Dinata

Tabel 4. Hasil Analisis Uji Validitas Angket

\begin{tabular}{cccc}
\hline Item & CVR & Item & CVR \\
\hline 1 & 1 & 14 & 1 \\
2 & 1 & 15 & 1 \\
3 & 1 & 16 & 1 \\
4 & 1 & 17 & 1 \\
5 & 1 & 18 & 1 \\
6 & 1 & 19 & 1 \\
7 & 1 & 20 & 1 \\
8 & 1 & 21 & 1 \\
9 & 1 & 22 & 1 \\
10 & 1 & 23 & 1 \\
11 & 1 & 24 & 1 \\
12 & 1 & 25 & 1 \\
13 & 1 & &
\end{tabular}

Tabel 5 berikut merupakan hasil analisis pengisian angket oleh mahasiswa dari masing-masing indikator setelah data diubah menjadi data interval.

Tabel 5. Hasil Analisis Angket

\begin{tabular}{ccc}
\hline Indikator & Skala & Kategori \\
\hline 1 & 3,9 & Siap \\
2 & 3,9 & Siap \\
3 & 3,8 & Siap \\
4 & 3,2 & Tidak Siap \\
\hline
\end{tabular}

Dengan mengacu skala kesiapan e-learning model Aydin dan Tasci (2005) seperti yang tertera pada Tabel 2, maka hasil analisis kesiapan mahasiswa terhadap $e$-learning memeroleh kategori siap pada indikator 1, 2, dan 3. Sedangkan pada kategori 4 menunjukkan kategori tidak siap. Kategori siap dan tidak siap yang diperoleh ini menurut model (Aydin \& Tasci, 2005) masih memerlukan adanya sedikit peningkatan.

Indikator 1 yaitu keterampilan komputer/smarthphone memeroleh skala rata-rata sebesar 3,9. Skala ini termasuk dalam kategori siap dengan memerlukan sedikit peningkatan. Secara lebih rinci, Gambar 1 menunjukkan skala dari masing-masing butir yang ada pada indikator 1.

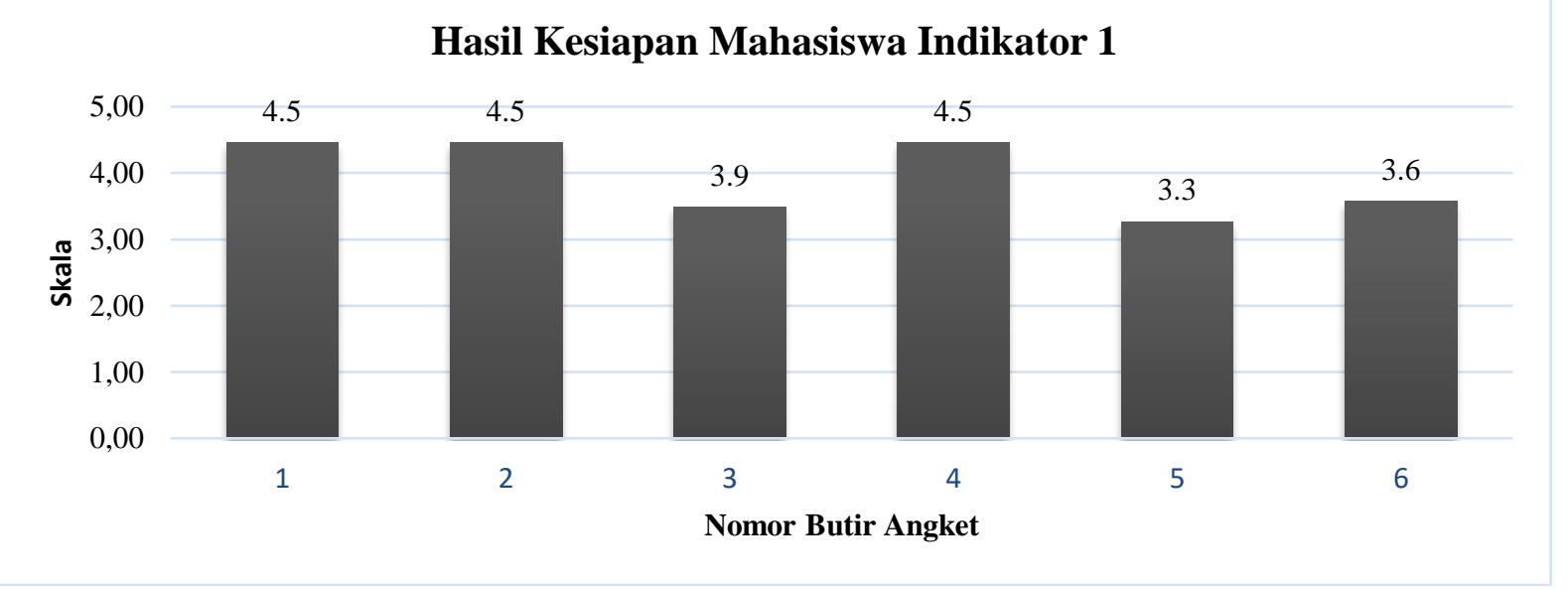

Gambar 1. Hasil Kesiapan Mahasiswa Indikator 1

Secara umum hasil pada indikator 1 ini menunjukkan bahwa mahasiswa Pendidikan Fisika sudah siap dalam menggunakan komputer, laptop, atau smartphone. Hasil ini ditunjukkan dengan nilai skala dari setiap butir pernyataan yang sudah di atas 3,3. Jawaban mahasiswa atas angket kesiapan e-learning menunjukkan bahwa secara umum para mahasiswa terampil dalam mengoperasikan komputer dan smartphone, baik secara software seperti Microsoft office, maupun hardware seperti penyimpanan pada drive. Mereka memiliki kemampuan mengetik serta memiliki pengalaman dalam memanfaatkan TIK dalam belajar. Karakteristik-karakteristik ini merupakan ciri khas dari generasi milenial, yaitu generasi yang aktif dan melek teknologi. 
Indikator 1 memiliki satu pernyataan yang memiliki skor 3,3 yaitu butir pernyataan nomor 5 . Pernyataan nomor 5 berisi "Saya mengetahui bagaimana cara menyelesaikan masalah pada komputer dan smartphone baik di sisi hardware maupun softwere.". Pada butir ini mahasiswa Pendidikan Fisika mendapatkan kategori belum siap artinya sebagian besar mahasiswa tidak tahu cara memperbaiki komputer atau smartphone jika terjadi kerusakan. Hal ini wajar karena perbaikan terhadap komputer, laptop, atau smartphone memerlukan keterampilan khusus yang tidak semua orang mempelajarinya. Dari sini dapat terlihat bahwa mahasiswa melek teknologi pada tingkatan user atau operator saja, namun belum memiliki kemampuan sebagai problem solver.

Butir pernyataan lain dalam indikator 1 ini sudah dinyatakan siap, namun masih dibutuhkan sedikit peningkatan menurut model Aydin dan Tasci (2005). Peningkatan ini bertujuan agar perkuliahan pada masa pandemi Covid-19 ini yang sepenuhnya menggunakan e-learning dapat berjalan optimal. Dengan mengetahui potensi-potensi mahasiswa yang ada, dosen atau institusi dapat mengambil kebijakan untuk mengembangkan keterampilan mahasiswa terkait penggunaan komputer sebelum melaksanakan e-learning. Kebijakan tersebut dapat berupa pelatihan atau workshop terkait tentang perbaikan teknis komputer atau smartphone. Hal ini sejalan dengan solusi yang diberikan Faslah dan Santoso (2017) pada Politeknik Hasnur di Kabupaten Barito Kuala, Kalimantan Selatan. Pelatihan yang diberikan tentu saja juga berupa media online dikarenakan situasi pandemi Covid-19. Pelatihan dapat berupa video tutorial yang dapat diikuti oleh mahasiswa melalui komputer atau smarthphone masing-masing.

Indikator 2 yaitu pemahaman terhadap teknologi e-learning memeroleh skala rata-rata sebesar 3,9. Skala ini termasuk dalam kategori siap dengan memerlukan sedikit peningkatan. Secara lebih rinci, Gambar 2 berikut menunjukkan skala dari masing-masing butir yang ada pada indikator 2.

\section{Hasil Kesiapan Mahasiswa Indikator 2}

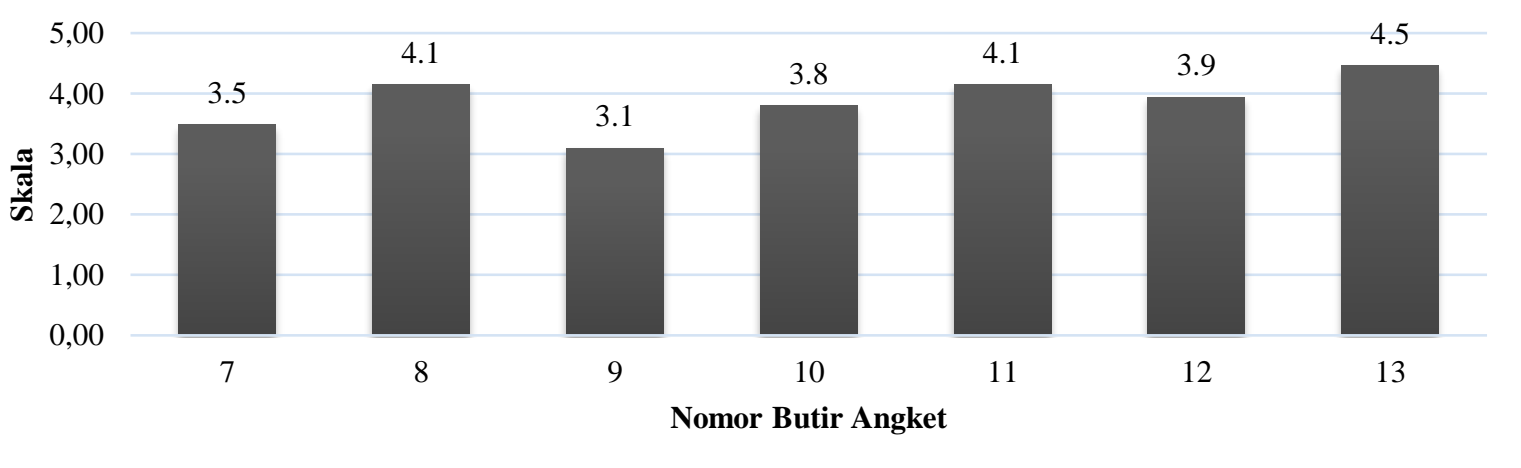

Gambar 2. Hasil Kesiapan Mahasiswa Indikator 2

Berdasarkan hasil pada Gambar 2, kesiapan mahasiswa pada indikator 2 dinyatakan dalam kategori siap. Indikator 2 menyatakan pemahaman terhadap teknologi e-learning. Hampir semua pernyataan dalam indikator 2 sudah dalam keadaan siap. Pengisian angket kesiapan e-learning memperlihatkan bahwa para mahasiswa telah paham tentang jaringan internet dan terbiasa menggunakannya dalam bersosial media. Mereka telah mengenal learning management system seperti Edmodo dan google classroom, dan dapat memanfaatkan fiturnya untuk mendukung pembelajaran. Para mahasiswa telah memiliki pengalaman dalam mengorganisasi sumber belajar di LMS. Lalu yang terakhir, para maha-siswa memahami bagaimana menggunakan video conference yang tentu sangat berguna dalam pembelajaran saat pandemi.

Butir pernyataan nomor 9 merupakan satu-satunya pernyataan yang berada pada kateori belum siap di indikator 2. Pernyataan ini berkaitan tentang "Saya memahami tata cara pelaksanaan pembelajaran online". Butir nomor 9 ini hanya mendapatkan nilai skala 3.1 dalam kategori tidak siap. Hal ini dikarenakan sebagian besar mahasiswa baru pertama kali melaksanakan perkuliahan penuh dengan sistem e-learning pada situasi pandemi Covid-19 ini. Hal ini menyebabkan mahasiswa belum terbiasa terkait dengan tata cara atau sistem pembelajaran e-learning. Ditambah lagi setiap mata kuliah dengan dosen yang berbeda memiliki tata cara dan sistem pembelajaran e-learning yang berbeda-beda.

Dibutuhkan kemampuan adaptasi yang baik dari mahasiswa untuk dapat siap menjalani pembelajaran e-learning. Hal ini sejalan dengan pernyataan dari Wannemacher (2006) bahwa kemampuan adaptasi yang baik sangat menentukan efektivitas e-learning. Dengan pembiasaan penggunaan $e$-learn- 
ing mahasiswa akan meningkatkan kemampuan untuk memahami tata cara pembelajaran online ini. Masih terkait dengan permasalahan pada indikator 1 butir pernyataan 4, memberikan pelatihan atau workshop yang tepat dapat menjadi solusi dari permasalahan ini.

Agar mahasiswa tidak kebingungan mengenai tata cara e-learning yang berbeda-beda, dibutuhkan suatu manajemen yang baik serta peningkatan kemampuan SDM sebagaimana disarankan oleh Fariani (2013). Dengan adanya manajemen SOP yang baik dan jelas, tata cara pelaksanaan e-learning akan lebih mudah dipahami mahasiswa.

Universitas Negeri Yogyakarta sudah menerbitkan petunjuk praktis pembelajaran daring UNY sesuai dengan Instruksi Rektor UNY Nomor 1 Tahun 2020. Prinsip pembelajaran yang digunakan pada Instruksi Rektor ini adalah pemanfaatan TIK untuk mendistribusikan konten pembelajaran, memantau aktivitas mahasiswa, dan menjalin interaksi dengan mahasiswa. Dosen-dosen diminta untuk memberikan konten belajar yang dapat diakses dari berbagai platform, seperti LMS hingga sosial media. Penggunaan sosial media untuk menyampaikan konten pembelajaran merupakan cara yang efektif dalam memanfaatkan potensi mahasiswa. Dengan mahasiswa yang telah terbiasa menggunakan social media, mengunggah atau mengunduh file, serta terampil dalam TIK, maka dosen dapat berfokus pada pengembangan konten pembelajaran ketimbang hal-hal teknis.

Indikator 3 yaitu kesiapan menerima materi pembelajaran melalui $e$-learning memperoleh skala rata-rata sebesar 3,8. Skala ini termasuk dalam kategori siap dengan memerlukan sedikit peningkatan. Secara lebih rinci, Gambar 3 menunjukkan skala dari masing-masing butir yang ada pada indikator 3 .

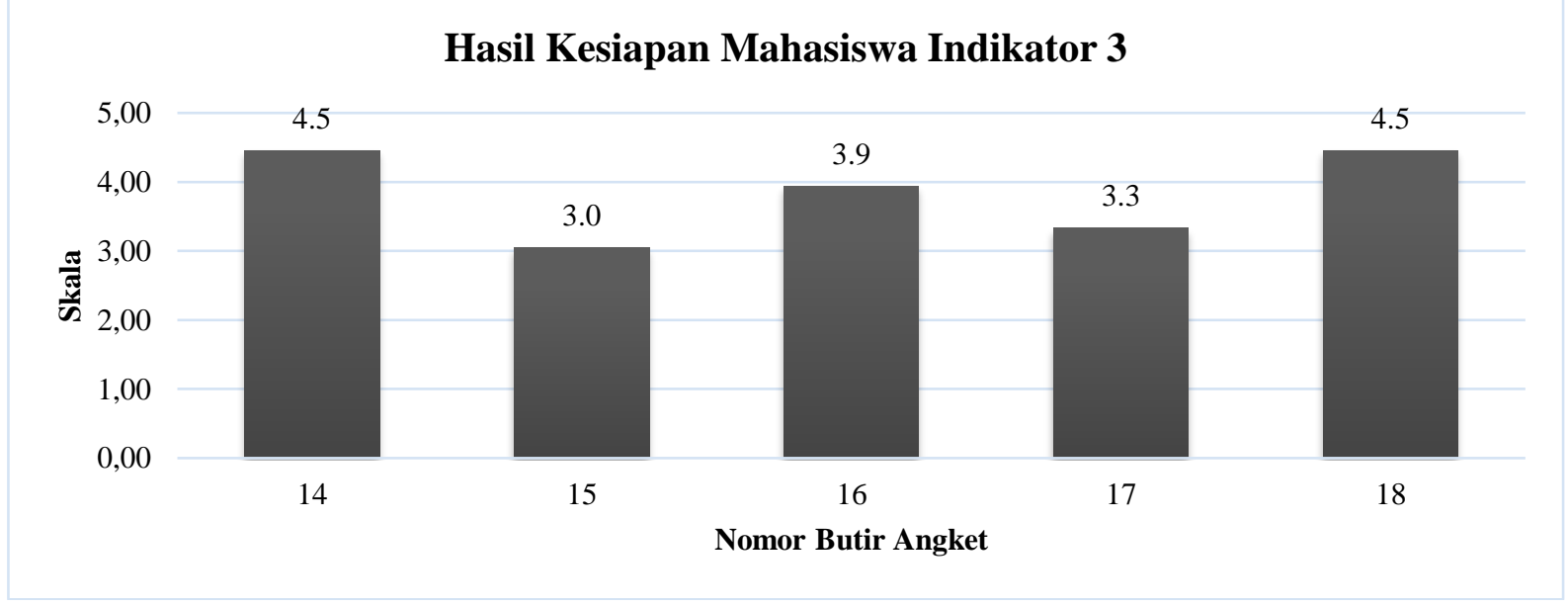

Gambar 3. Hasil Kesiapan Mahasiswa Indikator 3

Ada 5 butir pernyataan pada indikator 3. Tiga diantaranya sudah dinyatakan siap. Bahkan pada pernyatan 14 dan 18 sudah dinyatakan siap tanpa membutuhkan peningkatan, yaitu pernyataan tentang "Saya memiliki peralatan komputer atau smartphone" dan "Saya mengunduh dan mempelajari semua materi kuliah yang ada pada e-learning". Dari pernyataan-pernyataan ini dapat diketahui bahwa hardware bukan kendala bagi mahasiswa Pendidikan Fisika. Selain itu, mereka sebelumnya juga pernah menerima pembelajaran daring dan ikut berperan aktif pada pembelajaran tersebut.

Masih ada 2 butir yang dinyatakan belum siap pada indikator 3. Butir pernyataan dalam kategori belum siap yaitu butir 15 yang berisi "Saya memiliki koneksi internet yang memadai untuk melaksanakan pembelajaran online" dan juga butir 17 yang berisi "Saya mempersiapkan diri dengan belajar sebelum e-learning dimulai". Hal ini menjadi masalah karena mahasiswa tidak akan bisa menjangkau konten pembelajaran yang diberikan dosen jika tidak memiliki koneksi internet yang memadai dan kuota internet yang cukup. Universitas Negeri Yogyakarta memberikan kebijakan berupa bantuan kuota internet sebesar $30 \mathrm{~GB}$ untuk mahasiswa dalam menjalani e-learning berdasarkan Pengumuman Nomor B/417/UN34/KM.01/2020. Bantuan ini dapat diakses dengan mendaftarkan nama dan nomor hape terlebih dahulu. Dengan adanya bantuan ini diharapkan agar setiap mahasiswa memiliki koneksi internet yang memadai.

Persiapan yang kurang sebelum melaksanakan e-learning membuat mahasiswa dinyatakan belum siap pada butir ke 17. Sebagian besar mahasiswa belum mempersiapkan diri sebelum e-learning dimulai dikarenakan kontrol yang kurang dari dosen. Apabila kontrol dari dosen lebih diperketat pada pembelajaran e-learning sebagaimana pembelajaran tatap muka maka perseiapan mahasiswa akan lebih baik. 
Banyak fitur dari LMS yang tersedia untuk mengontrol mahasiswa dalam persiapan maupun pelaksanaan $e$-learning yang dapat dimanfaatkan dosen. Dosen-dosen dapat memberikan tugas awal yang harus dikerjakan mahasiswa terlebih dahulu sebelum pembelajaran inti dimulai. Tugas ini di desain sedemikian rupa agar mahasiswa perlu mencari informasi prasyarat terlebih dahulu. Dengan begitu, mahasiswa akan lebih siap ketika pembelajaran daring inti diberikan

Indikator 4 yaitu sikap positif mahasiswa terhadap teknologi komputer dan internet memeroleh skala rata-rata sebesar 3,2. Skala ini termasuk dalam kategori tidak siap dengan memerlukan sedikit peningkatan. Secara lebih rinci, Gambar 4 menunjukkan skala dari masing-masing butir yang ada pada indikator 4.

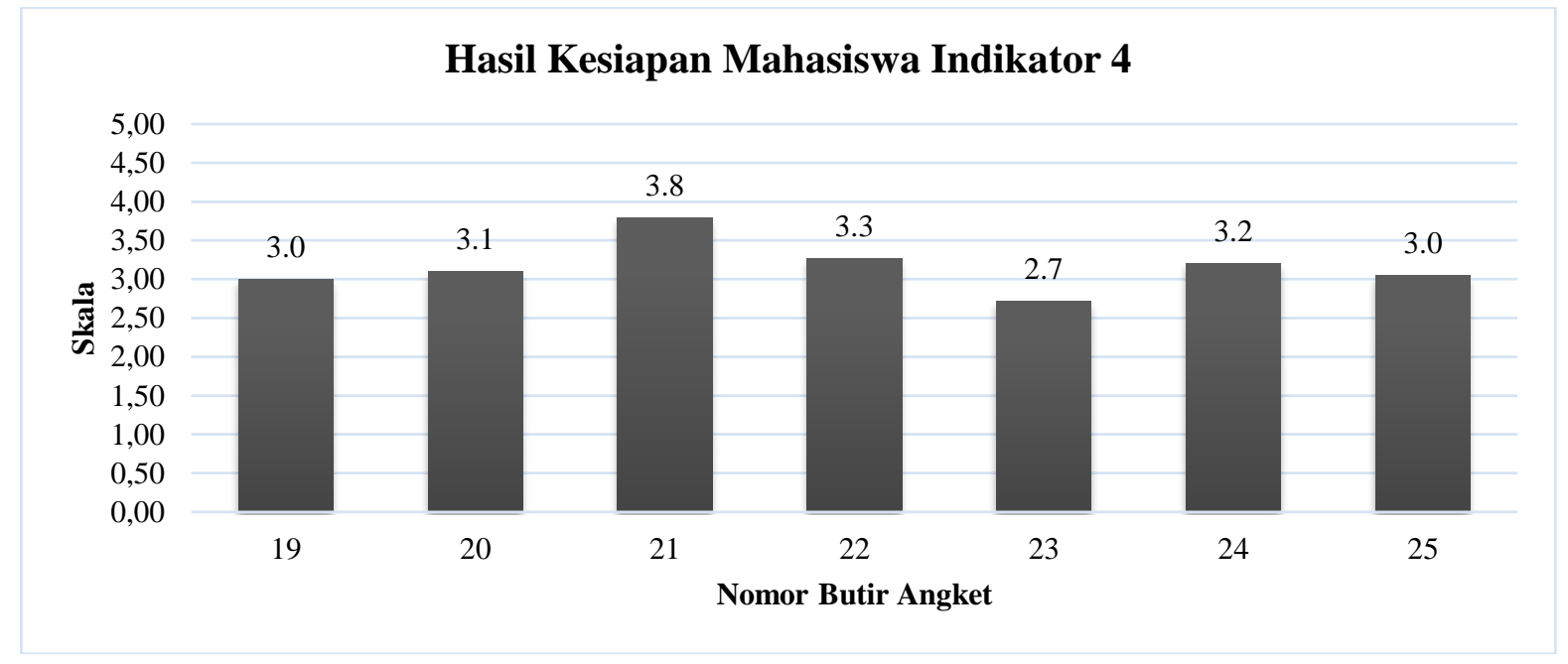

Gambar 4. Hasil Kesiapan Mahasiswa Indikator 4

Sebagian besar butir pada indikator 4 menunjukkan skala pada kategori yang tidak siap. Hanya ada satu butir berada pada kategori siap yaitu butir nomor 21 dengan skor 3.8 yang berisi "E-learning mempermudah saya dalam mengakses materi kuliah".

E-learning merupakan penggunaan teknologi informasi dan komunikasi pada proses belajar mengajar (Hasan, 2017; Muthuchamy \& Thiyagu, 2011; Rosenberg \& Foshay, 2002). Dengan pemanfaatan teknologi informasi, mahasiswa akan lebih mudah mengakses materi kuliah. Hal ini juga sejalan dengan (Al-Said, 2015; Ali et al., 2010) yang menyatakan bahwa pemanfaatan teknologi informasi dan komunikasi membuat perkuliahan menjadi lebih efektif.

Butir pernyataan lain selain butir nomor 21 menunjukkan hasil dalam kategori tidak siap. Kategori tidak siap ini membutuhkan sedikit penanganan sebelum pelaksanaan $e$-learning agar pelaksanaan $e$ learning dapat berlangsung lebih optimal.

Butir nomor 19 berisi "Kegiatan e-learning mampu meningkatkan minat belajar saya" dan butir nomor 20 berisi "E-learning meningkatkan motivasi belajar saya". Kedua butir tersebut masih dalam kategori tidak siap. Dengan berdasarkan dasar teori yang menunjukkan bahwa kegiatan e-learning mampu meningkatkan minta dan motivasi sebagaimana yang dinyatakan Wardono et al. (2016), seharusnya butir nomor 19 dan 20 dalam keadaan siap. Pemberian motivasi serta inovasi yang dilakukan dosen perlu ditingkatkan lagi pada pembelajaran e-learning ini. Hal ini bertujuan agar e-learning yang diberikan dosen dapat lebih menarik bagi mahasiswa dan menarik minat mahasiswa dalam mengikuti $e$ learning.

Butir nomor 22 berisi "E-learning meningkatkan kualitas berkomunikasi dengan dosen dan mahasiswa". Dan butir nomor 23 berisi "E-learning mempermudah saya dalam memahami materi perkuliahan serta tugas-tugas yang diberikan dosen". Kedua butir tersebut masih dalam kategori tidak siap. Berdasarkan hasil penelitian Al-Said (2015) penggunaan e-learning mampu meningkatkan komunikasi dalam perkuliahan. Namun pada kenyataannya masih dibutuhkan adaptasi bagi mahasiswa untuk dapat lebih optimal lagi dalam berkomunikasi dengan dosen melalui e-leraning. Sekali lagi hal ini sesuai dengan hasil penelitian dari Wannemacher (2006) yang menyatakan bahwa kemampuan adaptasi yang baik sangat menentukan efektivitas e-learning.

Butir nomor 24 berisi "E-learning meningkatkan kepercayaan diri saya dalam belajar." Penggunaan e-learning dalam perkuliahan secara teknis dapat meningkatkan kepercayaan diri mahasiswa. 
Mahasiswa dapat bebas menanyakan materi yang masih dianggap sulit secara langsung ke dosen tanpa harus merasa malu dengan temannya. Namun sikap positif ini belum optimal dimiliki oleh mahasiswa sehingga butir nomor 24 ini masih dalam kategori tidak siap. Meskipun begitu, pemberian edukasi dari dosen mengenai manfaat $e$-learning mampu menjadi solusi agar peranan e-learning dapat lebih optimal.

Butir nomor terakhir nomor 25 berisi "E-learning meningkatkan efektifitas waktu dalam pembelajaran". Pemahaman terkait dengan pelaksanaan e-learning masih belum optimal di kalangan dosen sehingga ada beberapa dosen yang hanya memberikan tugas online sebagai kuliah e-learning. Banyaknya tugas ini sangat membebani mahasiswa dari segi waktu sehingga mahasiswa menganggap e-learning tidak efektif dari segi waktu. Padahal menurut hasil penelitian dari (Ravitz \& Blazevski, 2014) e-learning mampu meningkatkan efektivitas waktu.

UNY sendiri sebenarnya sudah menjelaskan terkait teknis pelaksanaan $e$-learning yang dimuat dalam petunjuk praktis pembelajaran daring berdasarkan Instruksi Rektor UNY Nomor 1 Tahun 2020. Dengan pedoman itu dapat dijadikan dasar bagi dosen dalam pelaksanaan e-learning agar tidak membebani mahasiswa dengan pemberian tugas yang terlalu banyak.

Tiga dari empat indikator kesiapan mahasiswa dalam pelaksanaan $e$-learning menunjukkan kategori siap dan 1 indikator dalam kategori tidak siap. Masih dibutuhkan beberapa peningkatan dan penanganan untuk dapat mengoptimalkan pelaksanaan e-learning pada masa pandemi covid-19 sebagaimana yang sudah dijelaskan pada pembahasan di atas.

\section{SIMPULAN}

Berdasarkan pada hasil analisis dan pembahasan dapat ditarik simpulan bahwa mahasiswa Jurusan Pendidikan Fisika UNY sudah siap. Kategori siap yang diperoleh masih membutuhkan sedikit penanganan. 3 indikator kesiapan e-learning memeroleh kategori siap dengan memerlukan sedikit penanganan dan peningkatan, sedangankan 1 indikator dinilai belum siap dengan membutuhkan sedikit peningkatan. Peningkatan yang dapat dilakukan dapat berupa pemberian pelatihan atau workshop online untuk dosen dan mahasiswa, peningkatan manajemen e-learning, pemberian edukasi dan motivasi dari dosen untuk mahasiswa terkait sisi positif dari e-learning, serta peningkatan inovasi dosen agar $e$ learning yang dilaksanakan lebih menarik bagi mahasiswa.

\section{DAFTAR PUSTAKA}

Al-Said, K. M. (2015). Students' perceptions of edmodo and mobile learning and their real barriers towards them. Turkish Online Journal of Educational Technology-TOJET, 14(2), 167-180. http://www.tojet.net/articles/v14i2/14220.pdf

Ali, M., Djatmiko, I. W., Sigit, Y., \& Munir, M. (2010). Studi pemanfaatan e-learning sebagai media pembelajaran guru dan siswa SMK di Yogyakarta. Universitas Negeri Yogyakarta.

Angraini, A., \& Suryadi, D. (2015). Pengukuran tingkat kesiapan penerapan e-learning menggunakan TRI (Technology Readiness Index), Studi kasus: UIN SUSKA Riau. Sisfo, 05(03). https://doi.org/10.24089/j.sisfo.2015.03.003

Aydin, C. H., \& Tasci, D. (2005). Measuring readinesss for e-learning: Reflection from emerging country. Educational Technology and Society Journal, 8(4), 244-257. https://www.learntechlib.org/p/75035/

Azwar, S. (2015). Reliabilitas dan validitas. Pustaka Pelajar.

Dinata, P. A. C., Suparwoto, S., \& Sari, D. K. (2020). Problem-based online learning assissted by whatsapp to facilitate the scientific learning of 2013 Curriculum. Berkala Ilmiah Pendidikan Fisika, 8(1), 1. https://doi.org/10.20527/bipf.v8i1.7647

Fariani, R. I. (2013). Pengukuran tingkat kesiapan e-learning (e-learning readiness) (Studi kasus pada perguruan tinggi ABC di Jakarta). Seminar Nasional Aplikasi Teknologi Informasi (SNATI), 1(1). https://journal.uii.ac.id/Snati/article/view/3063

Faslah, R., \& Santoso, H. B. (2017). Analisis kesiapan implementasi e-learning menggunakan e-learning readiness model. POSITIF: Jurnal Sistem Dan Teknologi Informasi, 3(2), 113. https://doi.org/10.31961/positif.v3i2.431

Hasan, B. (2017). Teaching elementary mathematics using power point based screencast O-Matic 


\section{Jurnal Inovasi Pendidikan IPA, 6 (1), 2020 - 69}

Bayu Setiaji, Pri Ariadi Cahya Dinata

videos. INA-Rxiv. https://doi.org/10.17605/OSF.IO/728V9

Lawshe, C. H. (1975). A quantitative approach to content validity. Personnel Psychology, 28(4), $563-$ 575. http://caepnet.org/ /media/Files/caep/knowledge-center/lawshe-content-validity.pdf

Muthuchamy, I., \& Thiyagu, K. (2011). Technology and teaching: Learning skills. Gyan Publishing House.

Ravitz, J., \& Blazevski, J. (2014). Assessing the role of online technologies in project-based learning. Interdisciplinary Journal of Problem-Based Learning, 8(1). https://doi.org/10.7771/15415015.1410

Rektor Universitas Negeri Yogyakarta. (2020a). Instruksi Rektor Universitas Negeri Yogyakarta Nomor 1 Tahun 2020 tentang pelaksanaan kegiatan pembelajaran, layanan akademik, dan layanan umum untuk pencegahan penyebaran Covid-19 di Universitas Negeri Yogyakarta. Universitas Negeri Yogyakarta.

Rektor Universitas Negeri Yogyakarta. (2020b). Keputusan Rektor Universitas Negeri Yogyakarta Nomor 31.16/UN34/III/2020 tentang tim Covid-19 Crisis Center (3C). Universitas Negeri Yogyakarta.

Rektor Universitas Negeri Yogyakarta. (2020c). Surat Edaran Rektor Universitas Negeri Yogyakarta Nomor 1 Tahun 2020 tentang antisipasi penyebaran virus corona di Universitas Negeri Yogyakarta. Universitas Negeri Yogyakarta.

Rektor Universitas Negeri Yogyakarta. (2020d). Surat Edaran Rektor Universitas Negeri Yogyakarta Nomor 2 Tahun 2020 tentang kewaspadaan terhadap penyebaran Covid-19. Universitas Negeri Yogyakarta.

Rektor Universitas Negeri Yogyakarta. (2020e). Surat Edaran Rektor Universitas Negeri Yogyakarta Nomor 3 Tahun 2020 sebagai tindak lanjut dari Instruksi Rektor Universitas Negeri Yogyakarta Nomor 1 Tahun 2020 tentang pelaksanaan kegiatan pembelajaran, layanan akademik, dan layanan umum untuk pencegaha. Universitas Negeri Yogyakarta.

Rektor Universitas Negeri Yogyakarta. (2020f). Surat Edaran Rektor Universitas Negeri Yogyakarta Nomor 9 Tahun 2020 tentang pelaksanaan perkuliahan semester genap 2019/2020 pada masa tanggap darurat bencana Covid-19 di Universitas Negeri Yogyakarta. Universitas Negeri Yogyakarta.

Rosenberg, M. J., \& Foshay, R. (2002). E-learning: Strategies for delivering knowledge in the digital age. Performance Improvement, 41(5), 50-51. https://doi.org/10.1002/pfi.4140410512

Setiaji, B., \& Jumadi, J. (2018). Developing physics subject-spesific pedagogy on problem based learning model assisted by e-learning to enhance student's scientific literacy skill. International Journal of Sciences: Basic and Applied Research (IJSBAR), 37(3). https://www.gssrr.org/index.php/JournalOfBasicAndApplied/article/view/8933

Setiawan, R., Mardapi, D., Pratama, A., \& Ramadan, S. (2019). Efektivitas blended learning dalam inovasi pendidikan era industri 4.0 pada mata kuliah teori tes klasik. Jurnal Inovasi Teknologi Pendidikan. https://doi.org/10.21831/jitp.v6i2.27259

Setyoningsih, S. (2015). E Learning: Pembelajaran interaktif berbasis teknologi informasi. ELEMENTARY: Islamic Teacher Journal, 3(1). https://doi.org/10.21043/elementary.v3i1.1443

Shawar, B. A. A., \& Al-Sadi, J. A. (2010). Learning management systems: Are they knowledge management tools? International Journal of Emerging Technologies in Learning (IJET), 5(1). https://doi.org/10.3991/ijet.v5i1.887

Wannemacher, K. (2006). Functional differentiation of incentives for e-teaching at universities. Current Developments in Technology-Assisted Education, 72-76.

Wardono, Waluya, S. B., Mariani, S., \& Candra D, S. (2016). Mathematics literacy on problem-based learning with Indonesian realistic mathematics education approach assisted e-learning edmodo. Journal of Physics: Conference Series, 693, 012014. https://doi.org/10.1088/17426596/693/1/012014

Waryanto, N. H., \& Insani, N. (2013). Tingkat kesiapan (readiness) implementasi e-learning di sekolah menengah atas Kota Yogyakarta. Jurnal Pendidikan Matematika Dan Sains, 1(2), 117-124. 
Jurnal Inovasi Pendidikan IPA, 6 (1), 2020 - 70

Bayu Setiaji, Pri Ariadi Cahya Dinata

https://doi.org/10.21831/jpms.v2i2.2478

World Health Organization. (2020). Pertanyaan dan jawaban terkait Coronavirus. Who.Int. https://www.who.int/indonesia/news/novel-coronavirus/qa-for-public

World Health Organization. (2020). Coronavirus disease 2019 (COVID-19)Situation Report -71. https://www.who.int/docs/default-source/coronaviruse/situation-reports/20200331-sitrep-71covid-19.pdf?sfvrsn=4360e92b_8 